\title{
Menakar Pentingnya Perencanaan Karier untuk Warga Belajar Pada Penyelenggaraan Pendidikan Non Formal Program Pendidikan Kesetaraan
}

\author{
Riskiyana Prihatiningsih* \\ Universitas Negeri Malang, Jl. Semarang No. 5 Malang, Jawa Timur, Indonesia \\ *Penulis korespondensi, Surel: riskiyana.prihatiningsih.fip@um.ac.id
}

Paper received: 7-6-2021; revised: 21-6-2021; accepted: 28-6-2021

\begin{abstract}
This study was conducted with the aim of knowing the importance of career planning guidance for kelompok belajar paket $B$. The method used in this article is literature studies. The data used comes from sources such as journals and books relevant to the research theme. From some of the research that has been done, there is a positive relationship between career planning guidance and student career readiness.
\end{abstract}

Keywords: career guidance; career planning; career readiness; nonformal education; equality education

\begin{abstract}
Abstrak
Kajian ini dilaksanakan dengan tujuan untuk mengetahui pentingnya bimbingan perencanaan karier bagi warga belajar pada penyelenggaraan Pendidikan non formal. Kajian ini Metode yang digunakan dalam penulisan artikel ini adalah Kajian Literatur. Data yang digunakan berasal dari sumbersumber seperti jurnal dan buku yang relevan dengan tema penelitian. Dari beberapa hasil penelitian yang sudah dilakukan, terdapat hubungan yang positif antara bimbingan perencanaan karier dengan kesiapan karier peserta didik.
\end{abstract}

Kata kunci: bimbingan karier; perencanaan karier; kesiapan karier; pendidikan nonformal; pendidikan kesetaraan

\section{Pendahuluan}

Pemahaman terkait konsep pekerjaan dan karier merupakan pengembangan potensi diri dalam bidang karier yang terintegrasi dengan program bimbingan dan konseling dan program pendidikan pada umumnya (Astuti \& Purwanta, 2019) menjelaskan bahwa bimbingan karier merupakan upaya untuk membantu individu memecahkan berbagai masalah karier dalam memperoleh penyesuaian diri yang baik untuk menghadapi dan merencanakan masa depannya. Bimbingan karier merupakan istilah yang berangkat dari basis teoritis bagaimana seseorang berkembangan secara vokasional, bimbingan karier merupakan upaya membantu siswa dalam memecahkan masalah, menghindari konflik dan membuat kemajuan, efisiensi serta kepuasan dalam proses pencapaian tujuan masa depan (ASCA, 2003). Penyelenggaraan bimbingan karier yang berfungsi untuk membantu peserta didik dalam mengenali potensi diri, memecahkan berbagai permasalahan karier serta penyesuaian juga adaptasi diri dalam kontes karier serta merencanakan masa depan merupakan bagian dari penyelenggaraan bimbingan konseling. Penyelenggaraan layanan Bimbingan dan Konseling yang hanya pada tataran Pendidikan formal menjadi sebuah kajian kritis mengingat pentingnya bimbingan karier pada semua penyelenggaraan Pendidikan, baik formal dan non formal. 
Pendidikan diterjemahkan sebagai kegiatan pendidikan yang terorganisir yang diselenggarakan di luar sistem formal, baik tersendiri maupun merupakan bagian dari suatu kegiatan yang luas, yang dimaksudkan untuk memberikan layanan kepada sasaran didik tertentu dalam mencapai tujuan-tujuan belajar (Coombs \& Ahmed, 1974). Penyelenggaraan Pendidikan diluar sistem formal inilah yang membuat penyelenggaraan layanan bimbingan dan konseling tidak terjamah pada sistem Pendidikan non formal. Satuan pendidikan nonformal terdiri atas lembaga kursus, lembaga pelatihan, kelompok belajar, pusat kegiatan belajar masyarakat (PKBM), dan majelis taklim, serta satuan pendidikan yang sejenis. Ditengah cepatnya arus informasi dan teknologi dapat diakses dengan mudah, sehingga Pendidikan formal dianggap bukan hal yang utama sehingga pilihan mengambil Pendidikan non formal menjadi hal diminati oleh beberapa kalangan tertentu. Pemberian informasi terkait perencanaan karier kepada warga belajar di PKBM akan menjadi hal yang dibutuhkan dalam proses perencanaan karier bagi warga belajar yang kebanyakan adalah buruh pabrik, ibu rumah tangga, asisten rumah tangga atau anak-anak yang mempunyai kecenderungan untuk focus pada minat yang tinggi sehingga memilih menempuh Pendidikan pada jalur non formal.

Learning career akan berproses maksimal apabila terdapat layanan bimbingan karier pada layanan Pendidikan non formal (Hall \& Mirvis, 1995) karena nantinya pemilihan karier adalah yang penting dalam kehidupan masa depan peserta didik, karena karier merupakan mengenai diri sendiri, karier bicara soal pemenuhan kebahagiaan dan ketercapaian (fulfillment) (Suhardono, 2013). Tidakanaya penyelenggaraan layanan bimbingan karier pada layanan Pendidikan non formal menjadi sebuah perhatian khusus dan kajian sehingga menjadi sebuah rekomendasi bagi penyelenggara layanan Pendidikan non formal.

\section{Metode}

Desain penelitian yang digunakan pada penulisan artikel ini adalah literatur review. Literatur review merupakan metode penelitian untuk mengumpulkan data atau sumber terkait topik tertentu yang dapat diperoleh dari berbagai sumber referensi, seperti jurnal, buku atau sumber lain yang dapat dipertanggungjawabkan. Data ini diambil dari 19 artikel yang diterbitkan pada tahun 1974 hingga 2020 yang membahas tentang peran layanan bimbingan dan konseling pada sekolah formal, pentingnya layanan bimbingan karier pada berbagai jenjang Pendidikan, dan urgensi layanan bimbingan karier pada Pendidikan non formal dan Pendidikan kesetaraan. Sumber referensi yang dikaji diari berbagai sumber yang dapat dipertanggungjawabkan. Penelitian ini merupakan penelitian yang melakukan tinjauan literatur dari literatur atau dokumen yang mendukung dan bukan penelitian yang memperoleh data langsung dari responden (Sari \& Asmendri, 2020; Zed, 2004).

\section{Hasil dan Pembahasan}

\subsection{Hasil}

Berdasarkan literatur review yang telah dilakukan, terkait layanan bimbingan dan konseling pada sekolah formal, pentingnya layanan bimbingan karier pada berbagai jenjang Pendidikan, dan urgensi layanan bimbingan karier pada Pendidikan non formal. Layanan Pendidikan BK di sekolah formal adalah hal yang banyak disampaikan pada berbagai jurnal, utamanya di Indonesia. Penyelenggaraan bimbingan dan konseling tidak hanya terbatas pada setting sekolah yang namun pada corak setting Pendidikan non formal disampaikan oleh lebih dari 10 jurnal, lebih lanjut pelaksanaan layanan BK di Pendidikan non formal masih relatif rendah. Sedang kebutuhan akan layanan bimbingan dan konseling di Pendidikan non formal 
dipersentasekan $82,5 \%$ dari kajian artikel yang telah dilakukan dan 77,5\% membutuhkan layanan bimbingan karier dalam proses perencanaan individual.

\subsection{Pembahasan}

Menurut Brown, (2003) perencanaan karier merupakan proses individu, maka program perencanaan karier berfokus pada individu. Sejalan dengan perencanaan karier yang merupakan bagian dari bimbingan karier diartikan pelayanan dan aktivitas-aktivitas yang dimaksudkan untuk membantu para individu, pada semua usia dan sepanjang rentang kehidupan mereka untuk memilih pendidikan lanjutan, pelatihan dan pilihan karier serta mengelola karier mereka (Boyle \& Ribeiro, 2014). Pelayanan ini dijumpai di sekolah-sekolah, di universitas-universitas, dan perguruan tinggi, di instansi pelatihan, di biro kerja, di tempat kerja, di masyarakat, dan di biro jasa pelayanan. Aktivitas bimbingan karier dalam bentuk individual atau kelompok, baik secara tatap muka atau jarak jauh (seperti bantuan melalui jaringan dan pelayanan berbasis website). Diantaranya mencakup informasi karier, (bentuk cetakan, berbasis teknologi, komputer dan informasi maupun bentuk lainnya), assessment dan alat assessment diri, konseling, berbagai program pendidikan karier (untuk membantu para individu dalam mengembangkan kesadaran diri mereka, kesadaran adanya peluang, dan keterampilan-keterampilan dalam mengelola karier), berbagai program taster (pilihan-pilihan contoh sebelum mereka memilih), berbagai program pencarian kerja, dan pelayanan pengadaptasian (transition service). Komponen pelayanan-pelayanan dan aktivitas-aktivitas yang berlangsung di sekolah, agen-agen dan organisasi-organisasi lain yang memberikan konseling serta program-program pendidikan yang terkait dengan karier. Dalam definisi ini, bimbingan karier bisa diselenggarakan di sekolah maupun di luar sekolah yang mencakup semua bentuk aktivitas yang terkait dengan karier (Zunker, 2015). Pelayanan yang dijumpai di sekolah-sekolah dan universitas merupakan tataran layanan Pendidikan formal, sedang layanan bimbingan karier tidak dijumpai pada layanan Pendidikan nonformal sedangkan pelaksanaan layanan bimbingan karier bisa diselenggarakan pada di luar sekolah. Akan tetapi pada konteks Pendidikan non formal kekosongan layanan bimbingan dan konseling dilakukan oleh para tutor. Peran tutor pada penyelenggaraan Pendidikan nonformal adalah sebagai fasilitator dan konselor secara tidak langsung dalam menyelesaikan permasalahanpermasalahan yang dialami oleh warga belajar, baik motivasi belajar, kesadaran akan pentingnya proses pembelajaran serta membantu dalam memfasilitasi perencanaan individual (Asran, 2011; Khoirotin, 2020; Yustian, 2015).

Perencanaan individual merupakan bagian dari program bimbingan karier dalam penyelenggaraan layanan bimbingan dan konseling. Program perencanaan karier dapat dipersiapkan dengan menggunakan media bimbingan yang berupa modul, pamflet, ataupun brosur dalam bentuk satuan tertentu dan didesain sedemikian rupa guna memperlancar pelaksanaan layanan informasi dan bimbingan klasikal (Nursalim \& Naqiyah, 2010). Implementasi layanan bimbingan karier tentu melalui serangkaian prosedur sehingga layanan yang diselenggarakan tepat sasaran dan dilaksanakan oleh konselor profesional. Namun hal ini tidak dapat dilaksanakan karena pada program kesetaraan tidak terdapat konselor professional, dan peran tersebut dilaksanakan secara kuratif dan menyesuaikan dengan keadaan warga belajar. Kebutuhan warga belajar terhadap layanan bimbingan dan konseling di program kesetaraan ialah kebutuhan akan layanan bimbingan dan konseling, 2) warga belajar sangat membutuhkan layanan dasar, 3) warga belajar membutuhkan layanan responsif 
bimbingan dan konseling, 4) Sebagian besar warga belajar sangat membutuhkan layanan perencanaan individual bimbingan dan konseling (Erawati, 2012).

Minimnya layanan bimbingan karier pada penyelenggaraan non formal khususnya program kesetaraan berdampak pada ketidakmampuan warga belajar dalam mengenali bakat dan minat karier serta akan menghambat dalam memutuskan karier. Proses perencanaan merupakan proses yang sengaja dilakukan untuk : (1) menjadi sadar akan diri sendiri, (2) mengidentifikasi tujuan yang berkenaan dengan karier, (3) memprogramkan pekerjaan dan atau pendidikan yang berhubungan dengan pengembangan pengalaman guna memberikan pengarahan waktu dan konsekuensi langkah untuk mencapai tujuan tertentu. Kaitannya dengan hal ini, peserta didik dituntut terampil dan mampu dalam menyusun rencana kariernya khususnya untuk menentukan pilihan alternatif perencanaan kariernya (Storey, 2000). Proses ini membutuhkan bimbingan secara intensif yang dilakukan oleh konselor semestinya namun peran ini digantikan oleh tutor dengan bidang keilmuan diluar bimbingan dan konseling. Proses yang dinamis ini juga sangat dipengaruhi oleh faktor-faktor internal dan eksternal. Kemampuan intelegensi, bakat, minat, sikap, kepribadian, nilai, hobby atau kegemaran, prestasi, keterampilan, penggunaan waktu senggang, aspirasi dan pengetahuan pendidikan lanjutan, pengalaman kerja, pengetahuan tentang dunia kerja, kemampuan dan keterbatasan fisik dan penampilan lahiriah, masalah dan keterbatasan pribadi adalah faktor internal dalam proses perencanaan karier (Ummah, 2013). Sedangkan faktor eksternalnya, jumlah dan kesempatan kerja, jumlah dan sifat kesempatan latihan (training), kebijakan sosial dan prosedur seleksi peserta pelatihan karyawan, upah hasil berbagai pekerjaan, hukum perburuhan dan serikat kerja, peristiwa alam, perkembangan teknologi, perubahanperubahan pada organisasi sosial, sumber keluarga dan pengalaman latihan, sistem pendidikan, pengaruh masyarakat dan lingkungan, dan pengalaman belajar (Krumboltz, 1996). Faktor-faktor baik internal dan eksternal yang mempengaruhi perencanaan karier warga belajar ini, akan dapat diarahkan dalam layanan bimbingan karier yang nantinya membantu warga belajar dalam proses keputusan karier.

\section{Simpulan}

Pendidikan non formal khususnya program kesetaraan yang memfasilitasi masyarakat untuk mendapatkan fasilitas Pendidikan dengan berbagai latar usia serta sosial ekonomi yang membuatnya mempunya permasalahan yang begitu kompleks utamanya kaitan dengan karier. Warga belajar yang mengikuti program kesetaraan yang umumnya buruh pabrik, ibu rumah tangga, asisten rumah tangga atau anak-anak yang putus sekolah membutuhkan layanan bimbingan karier untuk melanjutkan masa depan yang lebih baik. Layanan bimbingan karier yang diselenggarakan pada Pendidikan formal saja, perlu perhatian sehingga layanan bimbingan karier dapat diselenggarakan oleh tutor dengan bantuan konselor profesional yang menjadi mentor dalam pelaksanaanya. Sehingga pelaksanan warga belajar dapat mengenali bakat dan minat kariernya dan mampu membuat keputusan karier berdasarkan minat kariernya.

\section{Daftar Rujukan}

ASCA. (2003). The ASCA National Model: A Framework for School Counseling Programs. Professional School Counseling. https://doi.org/10.2307/42732424

Asran, M. (2011). Pemetaan Masalah-Masalah Pendidikan Nonformal Di Kalimantan Barat:(Implikasi Terhadap Peningkatan Akses Layanan Pendidikan Bermutu). Jurnal Visi Ilmu Pendidikan, 5(2).

Astuti, B., \& Purwanta, E. (2019). Bimbingan Karier untuk meningkatkan Kesiapan karier. Devstudika. 
Jurnal Pembelajaran, Bimbingan, dan Pengelolaan Pendidikan, 1(6), 2021, 414-418

Boyle, L. E., \& Ribeiro, S. (2014). Organization for Economic Co-operation and Development.

Brown, D. (2003). Career information, career counseling, and career development. Allyn \& Bacon.

Coombs, P. H., \& Ahmed, M. (1974). Attacking Rural Poverty: How Nonformal Education Can Help. A Research Report for the World Bank Prepared by the International Council for Educational Development.

Erawati, A. (2012). Identifikasi Kebutuhan Layanan Bimbingan Dan Konseling Pada Warga Belajar Pendidikan Kesetaraan Kejar Paket C Di Sanggar Kegiatan Belajar (SKB) Kota Malang. SKRIPSI Jurusan Bimbingan Dan Konseling \& Psikologi-Fakultas Ilmu Pendidikan UM.

Hall, D. T., \& Mirvis, P. H. (1995). Careers as lifelong learning.

Khoirotin, F. (2020). Peran Tutor Dalam Meningkatkan Motivasi Belajar Peserta Didik. J+ PLUS UNESA, 9(2).

Krumboltz, J. D. (1996). A learning theory of career counseling.

Nursalim, M., \& Naqiyah, N. (2010). Media bimbingan dan Konseling. Surabaya: Unesa University Press.

Sari, M., \& Asmendri, A. (2020). Penelitian Kepustakaan (Library Research) dalam Penelitian Pendidikan IPA. Natural Science: Jurnal Penelitian Bidang IPA Dan Pendidikan IPA, 6(1), 41-53.

Storey, J. A. (2000). Fracture lines' in the career environment. The Future of Career, 21-36.

Suhardono, R. (2013). Your job is not your career. Literati.

Ummah, M. (2013). Penerapan Layanan Informasi Karier untuk Meningkatkan Kemampuan Perencanaan Karier Siswa Kelas XII SMAN I Krembung Sidoarjo. Jurnal BK UNESA, 1(1).

Yustian, G. (2015). Peran Tutor untuk Meningkatkan Motivasi Belajar Peserta Didik dalam Pembelajaran Mandiri. Jurnal Pendidikan Non Formal Dan Informal, 7(2).

Zed, M. (2004). Metode peneletian kepustakaan. Yayasan Obor Indonesia.

Zunker, V. G. (2015). Career counseling: A holistic approach. Cengage learning. 